\title{
FLUORESGENT FOCUS SIZE REDUCTION BY SPLEEN CELLS OF MICE IMMUNIZED WITH RABIES VIRUS
}

\author{
Yoshiniro Makino ${ }^{1}$ and Kumato Mifune 2 \\ Received for publication 20 March 1981
}

\begin{abstract}
The spread of rabies virus between adjacent mouse neuroblastoma cells was inhibited in the presence of spleen cells from mice sensitized to rabies virus as measured by the size of fluorescent focus formation. This activity of focus size reduction was appeared to be closely related to the development of cell-mediated cytotoxic activity. Rabies virus inactivated by beta-propiolactone was also capable of generating such an activity as live virus.
\end{abstract}

The role of cell-mediated immunity either in the recovery from primary rabies infection or in the postexposure immunoprophylaxis of rabies is poorly understood. Miller et al. (1978) have suggested the contribution of cell-mediated immunity in the recovery from rabies by demonstrating the potentiation of HEP rabies infection both in immunosuppressed and thymectomized mice. Kaplan et al. (1975) described similar observations. Recently, we have established the mouse model system by which the protection mechanisms of postexposure vaccination against rabies might be studied. The study has demonstrated that although interferon (IF), which is induced early after vaccination, is important, the postexposure prophylaxis of rabies cannot be elucidated simply by the IF nor neutralizing (NT) antibody produced by the vaccine and suggested the requirement of some other mechanisms including cellmediated immunity (Mifune et al., 1980).

Evidences indicating the development of cell-mediated immunity in rabies immunized animals have also been demonstrated by several in vitro and in vivo studies (Wiktor et al., 1974; Tignor et al., 1976; Wiktor et al., 1977; Lagrange et al., 1978; Tsiang \& Lagrange, 1980). However, whether these cell-mediated immune responses really play a role in the recovery or in the postexposure prophylaxis has not clearly been shown. Simmons et al. (1974) demonstrated that the in vitro control of the growth of herpes virus was quantified by determining plaque size in monolayers to which sensitized spleen cells were added as opposed to nonsensitized spleen cells and this method was a sensitive and more direct parameter to measure a cell-mediated immunity.

Present paper briefly describes that this technique is applicable to rabies virus and immune spleen cells are capable of limiting the spread of virus in the infected cell cultures.

$\mathrm{C} 3 \mathrm{H} / \mathrm{He}$ strain mice were immunized by intraperitoneal inoculation with ap-

1 Department of Virology, Institute for Tropical Medicine, Nagasaki University 2 Department of Microbiology, Medical College of Oita 
proximately $5 \times 10^{7}$ focus forming units(FFU) of live or the corresponding amount of beta-propiolactone(BPL) inactivated HEP-Flury strain of rabies virus (Kondo, 1965; Mifune et al., 1980). Spleens were harvested from the mice at various intervals after immunization. They were pressed gently through stainless steel mesh (\#200) and single cell suspensions were prepared in RPMI 1640 medium supplemented with 10 per cent heat-inactivated fetal calf serum(FCS). The single cell suspensions were then fractionated into the cells nonadherent to plastic plate and the effluent cells from nylon wool column as described by Julius et al. (1973). Cloned N-18 strain of mouse neuroblastome(MNB) cells were grown in Dulbecco's modified Eagle's medium supplemented with 5 per cent FCS, 5 per cent calf serum, $3 \mathrm{~g} / l$ of $\mathrm{NaHCO}$; and antibiotics and was plated into Lab-Tek 4-chamber slides (Miles lab.). When the cells became confluent, they were infected with $100 \mathrm{FFU}$ of plaque purified CVS strain of rabies virus (Buckley \& Tignor, 1975) and incubated at $37^{\circ} \mathrm{C}$ for $4 \mathrm{hrs}$. Whole or fractionated spleen cells from nonimmune or immune mice were carefully overlayed onto the infected MNB cells at a spleen cell to monolayer cell ratio of 50: 1 , and further incubated for $26 \mathrm{hrs}$ at $37^{\circ} \mathrm{C}$. Preliminary experiments indicated that during the $30 \mathrm{hrs}$ of incubation period, secondary fluorescent focus was not formed by the progeny virus from the primary infected focus. At the end of the incubation period, the culture media were harvested and the supernatants after low speed centrifufation were assayed for the activities of antiviral NT antibody, IF and lymphotoxin(LT) which might be produced in the co-cultivated culture. NT antibody was assayed as described by Smith et al. (1973) using CER cells (Smith et al., 1977), IF was assayed in L cells with vesicular stomatitis virus and LT was assayed as described by Shimizu et al. (1977) using L cells and MNB cells. On the other hand, infected MNB cells on the chamber slides were washed in phosphate buffered saline, fixed with cold acetone and then stained with FITC-conjugated anti-rabies globulin (BBL, \#40604). The number of cells in each immunofluorescent focus was conuted under a fluorescent microscope. At least, one hundred fluorescent foci were examined and the statistical significance of the focus size reduction was estimated by the analysis of variance.

Infected MNB cells co-cultivated with non-immune spleen cells (Fig. 1A) showed large fluorescent foci, usually consisting of 5-20 cells, whereas when co-cultivated with immune spleen cells (Fig. 1B), fluorescent foci were small, usually consisting of $1-5$ cells.

The effect of immune spleen cells harvested on day 7 after immunization on the focus size of rabies virus was shown in Table 1. The average focus size of the cultures co-cultivated with non-immune whole spleen cells was 6.2 cells, while that with immune whole spleen cells was 3.2 cells and the reduction rate of the focus size was 48.4 per cent which was statistically significant (Exp. 1). Depletion of plastic plateadherent cells from immune spleen cells did not influence the activity of immune spleen cells to limit focus size (Exp. 2). Effluent cells from nylon wool column consisted mostly of $\mathrm{T}$ cells as tested by rosette formation and this $\mathrm{T}$ cell-rich fraction also suppressed the virus spread by 47.3 per cent (Exp. 3). In contrast, pre-treatment of immune nonadherent spleen cells with anti-Thy 1.2 serum (OLAC, clone F7D5) plus complement before co-cultivation resulted in the abrogation of the activity 

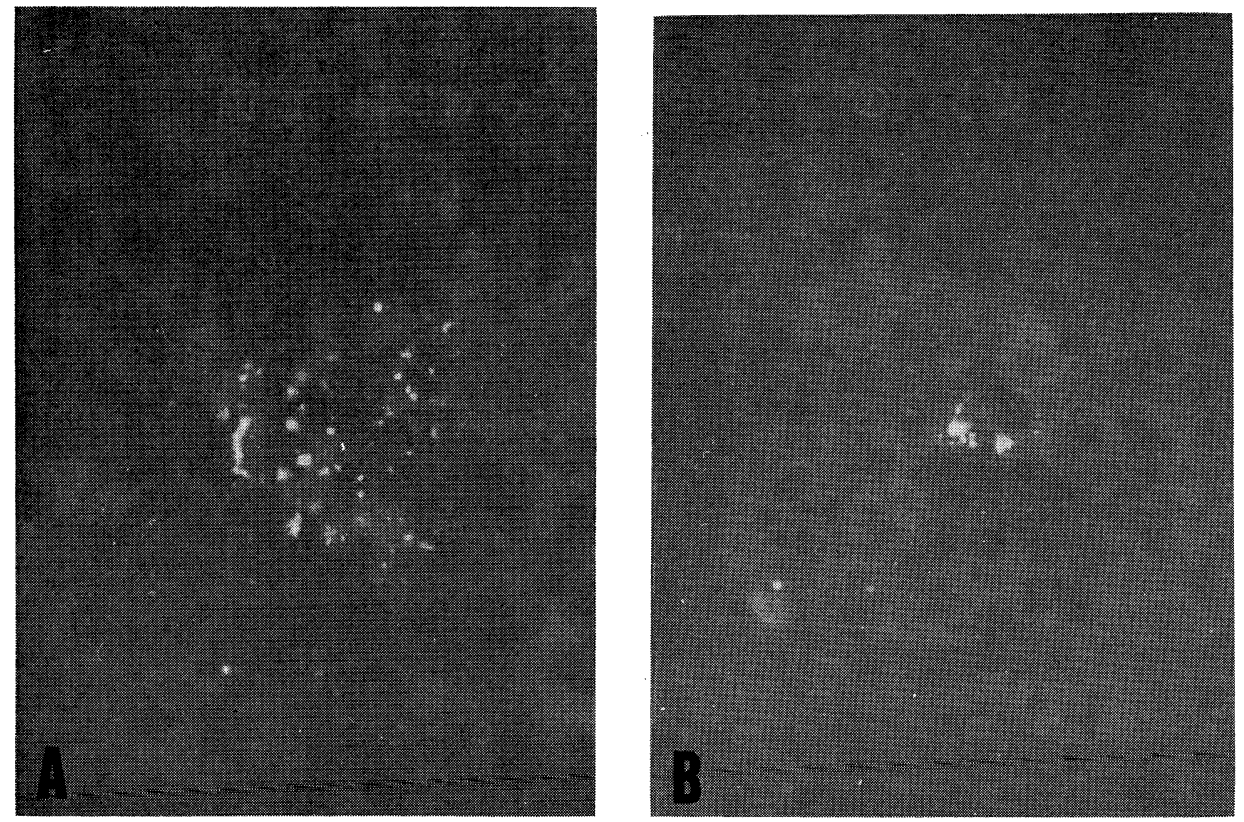

Figure 1 Immunofluorescent focus of rabies virus-infected murine neuroblastoma cells. The cells in the 4-chamber slides were infected with $100 \mathrm{FFU}$ per chamber of plaque purified CVS strain of rabies virus. Four hours later, the cells were carefully overlayed with (A) non-immune spleen cells or (B) rabies immune spleen cells and further incubated at $37 \mathrm{C}$ for 26 hours. Aftert he incubation period, the cell monolayers were washed with PSB, fixed with cold acetone and stained with FITC-conjugated anti-rabies gamma-globulin.

(Exp. 4). No significant inhibition of focus size was observed in the cultures cocultivated with spleen cells from mice immunized with Sindbis virus (Exp. 5). In addition, neither NT antibody, IF nor LT was detected in each of the co-cultivated MNB cell culture medium. These results appear to suggest that the suppression of virus spread by immune spleen cells is mediated by virus specific immune $T$ cells and not by the NT antibody, IF nor LT.

The kinetics of the development of focus size limiting activity after immunization is shown in Table 2. High activity was observed in the spleen cells obtained on day 6 after immunization. However, such high activity was no longer observed in the spleen cells harvested on day 14 . In parallel with this experiment, cell-mediated cytotoxic activities of spleen cell suspensions prepared at intervals after immunization were examined against virus infected $\mathrm{MNB}$ cells by ${ }^{51} \mathrm{Cr}$-release method. The results showed that the cytotoxic activity was first detected on day 4 and reached a maximum level on day 7 and then declined to a low level by day 14 (Data not shown) as already described by us and other investigators (Tignor et al., 1977; Mifune et al., 1979).

These results seemed to suggest that the suppression of virus spread by immune spleen cells is closely related with the development of the cytotoxic activity of immune 
Table 1 Fluorescent focus size reduction by immune spleen cells in rabies virus-infected murine neuroblastoma cells.

\begin{tabular}{|c|c|c|c|c|}
\hline Expt. & Effector cell population & $\begin{array}{l}\text { Fluorescent } \\
\text { focus size }\end{array}$ & $\begin{array}{l}\text { Reduction } \\
\text { rate }(\%)\end{array}$ & $\begin{array}{l}\text { Ab, IF and } \\
\text { LT assay }{ }^{\mathrm{b}}\end{array}$ \\
\hline \multirow[t]{2}{*}{1} & Normal whole spleen cells & 6.2 & & \multirow{2}{*}{$\begin{array}{l}\mathrm{Ab}(-) \\
\operatorname{IF}(-) \\
\operatorname{LT}(-)\end{array}$} \\
\hline & Rabies immune whole spleen cells & 3.2 & $48.4(\mathrm{SS})^{\mathrm{c})}$ & \\
\hline \multirow[t]{2}{*}{2} & Normal non-adherent spleen cells & 9.3 & & \multirow{2}{*}{$\begin{array}{l}\mathrm{Ab}(-) \\
\mathrm{IF}(-) \\
\mathrm{LT}(-)\end{array}$} \\
\hline & Rabies immune non-adherent spleen cells & 4.9 & $47.3(\mathrm{SS})$ & \\
\hline \multirow[t]{2}{*}{3} & Normal nylon wool column effluent cells & 11.0 & & \multirow{2}{*}{$\begin{array}{l}\mathrm{Ab}(-) \\
\mathrm{IF}(-) \\
\operatorname{LT}(-)\end{array}$} \\
\hline & $\begin{array}{l}\text { Rabies immune nylon wool column } \\
\text { effluent cells }\end{array}$ & 5.8 & $47.3(\mathrm{SS})$ & \\
\hline \multirow[t]{2}{*}{4} & $\begin{array}{l}\text { Rabies immune non-adherent spleen cells } \\
\text { treated with anti-Thy } 1.2+\text { complement }\end{array}$ & 6.6 & & \multirow{2}{*}{$\begin{array}{l}\mathrm{Ab}(-) \\
\mathrm{IF}(-) \\
\mathrm{LT}(-)\end{array}$} \\
\hline & $\begin{array}{l}\text { Rabies immune non-adherent spleen cells } \\
\text { treated with medium + complement }\end{array}$ & 2.1 & $68.2(\mathrm{SS})$ & \\
\hline \multirow[t]{2}{*}{5} & Normal non-adherent spleen cells & 7.9 & & \multirow{2}{*}{$\mathrm{NT}^{\mathrm{e})}$} \\
\hline & $\begin{array}{l}\text { Sindbis virus immune non-adherent spleen } \\
\text { cells }\end{array}$ & 5.6 & $29.1(\mathrm{NSS})^{\mathrm{d})}$ & \\
\hline
\end{tabular}

a) Average number of cells an fluorescent focus consisted.

b) $\mathrm{Ab}$ (NT antibody), IF (Interferon) and LT (Lymphotoxin) in cocultivated culture media were assayed as described in the text.

c) Statistically significant, $\mathrm{P}<0.01$ by analysis of variance. d) Not statistically significant. e) Not tested.

Table 2 Development of fluorescent focus size reduction activity of spleen cells from mice immunized with live or BPL-inactivated rabies virus.

\begin{tabular}{|c|c|c|c|c|c|}
\hline $\begin{array}{l}\text { Days spleen } \\
\text { cells harvested } \\
\text { after } \\
\text { immunization }\end{array}$ & Effector cells & Stimulant & $\begin{array}{l}\text { Fluorescen } \\
\text { non-immune } \\
\text { effector }\end{array}$ & $\begin{array}{l}\text { th focus size }{ }^{\mathrm{a})} \\
\text { vith } \\
\text { rabies immune } \\
\quad \text { effector }\end{array}$ & $\begin{array}{c}\text { Reduction } \\
\text { rate } \\
(\%)\end{array}$ \\
\hline 6 & $\begin{array}{l}\text { nylon wool column } \\
\text { effluent cells }\end{array}$ & live & 14.1 & 6.0 & $57.4(\mathrm{SS})^{\mathrm{b})}$ \\
\hline 14 & $\begin{array}{l}\text { nylon wool column } \\
\text { effluent cells }\end{array}$ & live & 14.1 & 10.1 & $28.4(\mathrm{NSS})^{\mathrm{c})}$ \\
\hline 6 & $\begin{array}{l}\text { non-adherent } \\
\text { spleen cells }\end{array}$ & BPL-inactivated & 19.8 & 7.6 & $61.6(\mathrm{SS})$ \\
\hline 14 & $\begin{array}{l}\text { non-adherent } \\
\text { spleen cells }\end{array}$ & BPL-inactivated & 19.8 & 12.3 & $37.8(\mathrm{SS})$ \\
\hline
\end{tabular}

a) Average number of cells an fluorescent focus consisted.

b) Statistically significant, $\mathrm{P}<0.01$ by analysis of variance.

c) Not statistically significant.

spleen cells. It should be noted that BPL-inactivated rabies virus is also capable of generating the activity of spleen cells to limit the virus spread as live virus. This observation might be of interest in terms of the possible role of cell-mediated immunity in the postexposure treatment of rabies by BPL-inactivated vaccine. 


\section{ACKnowledgement}

A part of the study was supported by the grant from the Japan-United States Cooperative Medical Science Program.

\section{REFERENCES}

1) Buckley, S. M. \& Tignor, G. H. (1975): Plaque assay for rabies serogroup viruses in Vero cells, J. Clin. Microbiol., 1, 241-242

2) Julius, M. H., Simpson, E. \& Herzenberg, L. A. (1973): A rapid method for the isolation of functional thymus-derived murine lymphocytes, Eur. J. Immunol., 3, 645-649

3) Kaplan, M. M., Wiktor, T. J. \& Koprowski, H. (1975): Pathogenesis of rabies in immunodeficient mice, J. Immunol., 114, 1761-1765

4) Kondo, A. (1965): Growth characteristics of rabies virus in primary chick embryo cells, Virology, 27, 199-204

5) Lagrange, P. H., Tsiang, H., Hurtrel, B. \& Ravisse, P. (1978): Delayed-type hypersensitivity to rabies virus in mice: Assay of active or passive sensitization by the footpad test, Infect. Immun., 21, 931-939

6) Mifune, K., Nakamura, M. \& Mannen, K. (1979): Persistent infection of avirulent strain of rabies virus in immunosuppressed mice, Trop. Med., 21, 131-138

7) Mifune, K., Schichijo, A., Makino, Y., Takeuchi, E., Yamada, A. \& Sakamoto, K. (1980): A mouse model for the pathogenesis and postexposure prophylaxis of rabies, Microbiol. Immunol., 24, 835-845

8) Miller, A., Morse, H. C. III., Winkelstein, J. \& Nathanson, N. (1978): The role of antibody in recovery from experimental rabies. I. Effect of depletion of $\mathrm{B}$ and $\mathrm{T}$ cells, J. Immunol., 121, 321-326

9) Shimizu, F., Hanaumi, K., Shimizu, Y. \& Kumagai, K. (1977): Antibody-dependent cellular protection against herpes simplex virus dissemination as revealed by viral plaque and infectivity assays, Infect. Immun., 16, 531-536

10) Simmons, R. L., Centifanto, Y. \& Kaufman, H. E. (1974): Plaque size reduction as a measure of viral cell-mediated immunity, Infect. Immun., 10, 1034-1039

11) Smith, A. L., Tignor, G. H., Mifune, K. \& Motohashi, T. (1977): Isolation and assay of rabies serogroup viruses in CER cells, Intervirol., 8, 92-99

12) Smith, J. S., Yager, P. A. \& Baer, G. M. (1973): A rapid reproducible test for determining rabies neutralizing antibody, Bull. W.H.O., 48, 535-541

13) Tignor, G. H., Mifune, K. \& Smith, A. L. (1976): The immunopathology of rabies, pp. 13-14. In Symposium on advances in rabies research. Atlanta, U.S. Department of Health, Education and Welfare.

14) Tsiang, H. \& Lagrange, P. H. (1980): In vivo detection of specific cell-mediated immunity in street rabies virus infection in mice, J. Gen. Virol., 47, 183-191

15) Wiktor, Y.J., Doherty, P. C. \& Koprowski, H. (1977): In vitro evidence of cell-mediated immunity after exposure of mice to both live and inactivated rabies virus, Proc. Natl. Acad. Sci., 74, 334-338

16) Wiktor, T. J., Kamo, I. \& Koprowski, H. (1974): In vitro stimulation of rabbit lymphocytes after immunization with live or inactivated vaccines, J. Immunol., 112, 2013-2019 
狂犬病ウイルス免疫マウス脾臓細胞によるウイルス螢光フォーカス形成抑制 牧 野 芳 (1) $^{1)}$ 三 舟 求真人 ${ }^{2)}$

狂犬病ウイルス (HHp-Flury 株) で免度されたマウス脾細胞は，マウス神経芽細胞腫 (MNB) 細 胞上でのウイルスの螢光フォーカス形成を有意に抑制した。脾細胞のこのウイルス伝播抑制作用は, 脾細胞からプラスチック面付着細胞を除去しても活性が消失しないてと, ナイロン綿カラム通過細胞 亿認められること, 脾細胞を予め, 抗 Thy-1.2 血清と補体で処理すると活性が消失するてと, MNB 細胞と免疫脾細胞の混合培養液中に, ウイルス中和抗体，インターフェロン或いはリンホトキシンが が検出されないとと等から， Tリンパ球によるととが明らかであった。また，乙の活性は，同時に行 なった免疫脾細胞のウイルス感染 MNB 細胞に対する細胞障害活性の発現と時期を同じくして発現 し, 脾細胞の細胞障害活性と密接な関係があるととが示された。また， $\beta$-プロピオラクトンで不活化 されたウイルスで免疫されたマウス脾細胞にも，生ウイルスと同椂にてのウイルス伝播抑制作用が認 められ，不活化ワクチンによる狂犬病のいわゆる感染後投与による発症防御機構に，細胞性免疫が一 つの役割を果たしている可能性を示唆するすのとして興味深い。

長崎大学熱帯医学研究所ウイルス学部門1) 及び大分医科大学医学部微生物学講座 ${ }^{21}$ 